\title{
Feminist Knowledge Production in Europe on Diplomacy and International Negotiation
}

\author{
Tonka Kostadinova
}

\begin{abstract}
This chapter traces the development of feminist scholarship in Europe on diplomacy and international negotiation. Sensitive to variations between different national contexts, this chapter suggests that the state frames the broader socio-political environment, which incentivizes or discourages the creation of feminist knowledge. This chapter also provides important insights on prevailing silences and limitations of existing research. By outlining both the thematic and the geographical discrepancies in feminist knowledge production on diplomacy across Europe, this chapter calls attention to the systematic disregard of gender as a category of analysis in many European countries and offers useful avenues for further research.
\end{abstract}

Keywords Gender - Diplomacy · International negotiation - The state · Feminist knowledge production

T. Kostadinova $(\bowtie)$

University of Burgas, Burgas, Bulgaria

(C) The Author(s) 2022

M. Stern and A. E. Towns (eds.), Feminist IR in Europe,

Trends in European IR Theory,

https://doi.org/10.1007/978-3-030-91999-3_8 


\section{INTRODUCTION}

Over the last two decades, feminist studies in Europe on diplomacy and international negotiation have evolved into a dynamic inter-disciplinary research field, offering an inspiring vision of gender history, women's representation, and the shifting empowerment of men and women in international affairs across time. A significant number of scholars in Europe have contributed to rethinking and re-conceptualizing diplomacy as a gendered practice and study, joining the global feminist international relations (IR) debates, which sought to unveil the gendered character of international politics and of the key concepts employed in the field.

The growing scholarly interest in the gendered dynamics in diplomacy has been incentivized by the profound transformations in the field, related to the twentieth-century historical opening up of the diplomatic service for women and the enhanced recognition of their role in international politics. The latter in turn has been part of a broad and coherent shift in the political culture of European societies, headed toward greater women's participation in political life and in higher level decision-making. Not every European society, though, has experienced these processes in the same way. A society's values and religious beliefs, its institutions and leaders, and the structure of the state all have impacted the process of women's political empowerment, including in the area of diplomacy, and have shaped the wider context, which stimulates or discourages feminist knowledge production in the field.

Informed by the understanding that gender discourses and feminist knowledge take shape within particular political and socio-economic environments, which has the potential to model scholarly interest, methods, approaches, and production, this chapter sets out to explore whether and how different national contexts of Europe may influence scholarly efforts to integrate gender into foreign policy and diplomacy research. It will do so by exploring the relationship between the creation of feminist knowledge and the location of this endeavor. Accordingly, this chapter presents an unique data-base of Europe-based scholars on gender and diplomacy and provides the first of its kind geographical mapping of existing European scholarship in the field.

This chapter considers a rich body of literature from a number of disciplines-political science, international relations, policy studies, history, and sociology, but does not aim to explore the full extent of the theoretical, methodological, and epistemological diversity of feminist scholarship 
on diplomacy and international negotiation in Europe. It rather charts broader patterns in Europe by discussing the key thinkers who have contributed to establishing gender as a relevant category of analysis in diplomacy and by analyzing the prevailing theoretical and methodological approaches in their research.

A dialogue across the main realms of feminist scholarship in Europe on diplomacy and international negotiation provides important insights on prevailing silences and limitations of existing research in the field. By outlining both the thematic and the geographical discrepancies in feminist knowledge production on diplomacy across Europe, this paper calls attention to the systematic disregard of gender as a category of analysis in many European countries and offers useful avenues for further research.

\section{Mapping Feminist Scholarship on Diplomacy and International Negotiation Across Europe}

\section{Mapping Across States}

Over the last decade and a half, feminist scholarship in Europe on diplomacy and international negotiation has taken on a multifaced direction, contributing to positioning Europe as a key scientific "player" in the field. The dynamics of feminist knowledge production, though, seem to vary quite radically between the European countries. This variation is associated with the different political, economic, and social contexts in which feminist knowledge is created, articulated, and disseminated. This chapter provides a unique mapping of scholars in Europe who have developed and integrated gender perspectives and approaches in their research on diplomacy and international negotiation, identifying their current place of work. Altogether, 52 scholars were examined across 13 European states. Most of the scholars have explicitly identified their work as feminist, others have simply integrated women's perspectives in their wider research on diplomacy, but all of them made manifest the issue of gender, which, until very recently, was invisible in mainstream diplomacy studies. The mapping is limited to feminist scholarship published in English and German. It thus might say more about where scholars are located who publish in English or German than it does about feminist diplomacy scholarship as such.

The mapping illuminates that feminist knowledge on diplomacy in English and German has been created primarily across Western Europe 

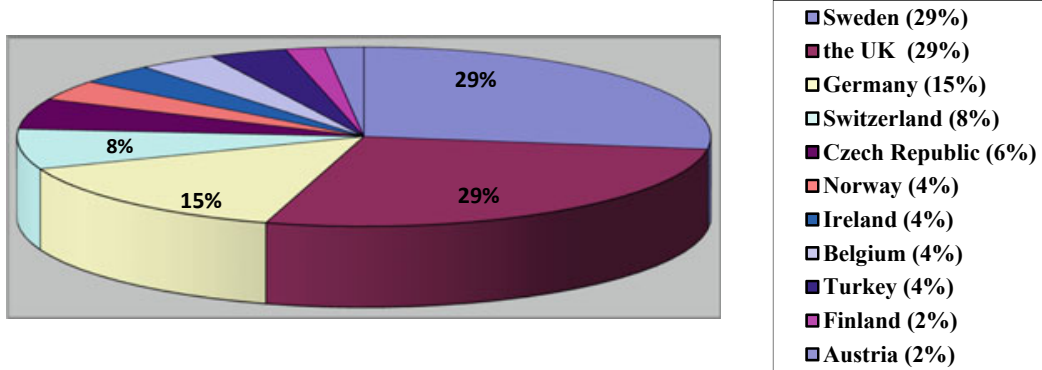

Fig. 8.1 Distribution of feminist IR scholars on diplomacy among European states $(n=52)$

and the Scandinavian states and is particularly pronounced in the UK and Sweden, which can be viewed as "pioneers" in developing the field within Europe. The review of the literature shows that UK-based and Swedenbased scholars have produced the largest number of publications, offering a rich strand of theoretical and empirical research on gender in diplomacy.

UK universities and research centers host 15 (29\%) out of the 52 scholars in the mapping. Equal number of the scholars surveyed are based in Sweden (29\%). Other European countries, most notably Germany, Switzerland, Austria, Belgium, Ireland, Norway, and Finland, are also on the map of feminist studies on diplomacy and international negotiation in Europe, as shown in Fig. 8.1. At the same time, entire European regions, such as Eastern and Southern Europe, are missing from the chart. ${ }^{1}$

The mapping elucidates the key role of the national context not only in terms of institutional frameworks and funding to feminist research projects, but also in securing the wider socio-political context for the legitimization and appropriation of feminist knowledge. Feminist approaches to diplomacy and international negotiation seem to find a suitable home mostly in countries, which advance pro-gender norms and strategies in foreign affairs or have invested resources in constructing their image as women-friendly states. The pursuit of women's rights or gender mainstreaming in foreign policy, as in the UK and Sweden, might serve as an important push factor, which shapes scholarly interest,

${ }^{1}$ Important exceptions here are the Czech Republic and Turkey, where we have evidences of local scholars who have made efforts to integrate gender perspective in their research on diplomacy, and more broadly—on foreign policy and IR. 
methods, approaches, networking, and collaborations, and incentivizes feminist research in the field.

The concentration of studies within Western Europe and the Scandinavian states suggests that feminist scholarship produced in Europe is focused predominantly on the history and experiences of women in liberal democracies and in Western European diplomacy. With very few exceptions, the gendered diplomatic practices in non-democratic regimes, such as those in post-WWII Portugal, Spain, or in communist Central and Eastern Europe (CEE), remain silenced. A more sophisticated engagement of feminist scholars with the Southern and Eastern region might provide new theoretical perspectives on the relationship between gender, diplomacy, and the legacy of contrasting political regimes-democracy, authoritarianism, and state socialism.

As a general trend, feminist knowledge production on diplomacy and international negotiation has remained marginalized in countries lacking rights-oriented and women-friendly politics. Across CEE, feminism remains a matter of political and intellectual courage and the costs of asserting a feminist position in academia range from continuous public humiliation and uncensored slander to crude censorship and the loss of academic status (Bucur 2008: 1381). Moreover, attacks on feminism and gender equality have become a steady aspect of recent de-democratization trends in the region and have impacted both feminist knowledge production and the transmission of feminist knowledge (Krizsan and Roggeband 2019). Against the context of limited funding resources and the lack of institutional and public support, feminist knowledge production in the region is almost fully dependent on the personal commitment of local scholars. The need to articulate and defend feminist ideas, methods, and approaches within a gender-hostile academic and socio-political environment discourages many efforts toward the creation of feminist knowledge, especially in the traditionally andro-centric fields of political science and international relations.

\section{Mapping Across Institutional Sites}

\section{University Sites}

The most active channel for the distribution of funds to feminist research projects and hence an important institutional factor for the development of the field are European institutions of higher education with expertise 


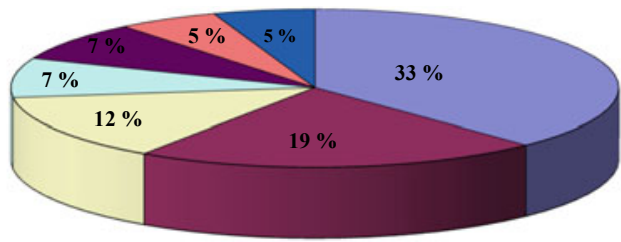

DDepartments of History

口Departments of Political Science

口IR Departments

口Faculty of Arts and the Hummanities

DDepartments of Global Political (or

Transnational) Studies

口Departments of Sociology

$\square$ Departments of Peace and Conflict

Fig. 8.2 Distribution of feminist IR scholars on diplomacy among university departments

in basic (as opposed to applied) research in social sciences and the humanities, concentrated in Western and in Northern Europe. As a general European trend, feminist scholarship on diplomacy has rarely developed within departments of gender or women's studies, but rather within departments of history, political science, and IR, as indicated in Fig. 8.2.

\section{Non-University Research Centers}

Non-university research centers play a growing role in the construction of feminist knowledge in the area of diplomacy and international negotiation. They prioritize feminist research that has the potential to be highly relevant to policy and provide examples of more applied literature. Scholarly output is usually disseminated in the form of policy papers and policy reports and is based on both quantitative indicators (e.g. gender equality indexes) and qualitative data. Much of the feminist scholarship across non-university research centers in Europe is created by former practitioners in the field and reflects their professional experience and engagement to bridge research to the demands of policy. The fact that many practitioners continue their career as advisers or researchers in the non-university sector partially explains why scholarship on women in international negotiation (as compared to diplomatic history scholarship) is distributed in a more balanced way between universities, research centers, and non-governmental organizations. 


\section{Diplomatic Academies and Research Centers Attached to the Ministries of Foreign Affairs (MFAs)}

Considering the conspicuous relationship between feminist research and the demands of policy, it is reasonable to expect that European Ministries of Foreign Affairs (MFAs), through their research infrastructure, take active part in the global debates on the role and status of women in diplomacy. However, with very few exceptions, this has not been the case. The British Foreign Office is one of the few state agencies that has initiated a comprehensive analysis on the diverse ways in which women have influenced the work of the institution throughout its existence (Crowe et al. 2018). In 2020, the German MFA also issued a highly timely report on gender equality in the Federal Foreign Office, aimed at raising the public profile of female diplomats and at demonstrating the importance of equity between men and women in the German Foreign Service. ${ }^{2}$ These two exceptions notwithstanding, the potential of MFAs and their diplomatic academies to produce gender-oriented research or to integrate gender perspectives in their training programs remains untapped. More active engagement of diplomatic institutions in feminist knowledge production has the potential to not only inspire and infuse feminist perspectives to national foreign policy agendas, but also enrich the global feminist IR debates, by providing unique access to important primary sources and to the relevant institutional and social environment, necessary for diversifying the methods and approaches applied in the field.

\section{Mapping Key Thinkers on Gender and Diplomacy in Europe}

In the last decade and a half, an increasing number of scholars in Europe have become interested in studying the gendered dynamics of diplomacy and have built a solid knowledge base. In the discussion that follows, this chapter discusses scholars in Europe who have been central to the establishment of gender as a relevant category of analysis in the malecentered academic terrain of diplomacy and international negotiation. It is important to emphasize that no single article can do proper justice to the vitality of feminist thought in the area of diplomacy, and the scholars

\footnotetext{
2 "Gender equality in German foreign policy and in the Federal Foreign Offce." [online].
} 
discussed further on by no means match the total number of scholars, who, through their inspiring and innovative research, have contributed to the development of the field.

Given the limits of this chapter, I have chosen to select those scholars, whose writings reveal "flaws" in feminist scholarship in Europe on diplomacy. This chapter distinguishes two main streams of thought, along which scholars in Europe and their contributions are grouped and discussed-the study of women through the prism of diplomatic history and the study of the gendered nature of contemporary diplomatic institutions, practices, and norms.

The field of diplomatic history evidences a particular wealth of feminist studies and has developed in a number of European countries-most notably, the UK, Sweden, Germany, Norway, Ireland, and Austria. The most extensive accounts on the history of women in diplomacy stem from the UK. UK-based scholars are among the first exponents of historical approaches, elucidating the informal roles that women have indirectly played in international activities before gaining formal access to diplomacy. James Daybell (University of Plymouth), for example, studies women's political influence in the early modern period, focusing on women's engagement in diplomatic and intelligence activities through informal and family channels (Daybell 2004, 2011, 2016). He approaches women's wide-ranging social activities as political and uses female letterwriting as a relevant source material for the historical reconstruction of women's interest and involvement in areas, traditionally dominated by men (e.g. war, armed rebellions and naval preparations). Daybell's major contribution lies in illuminating the importance of re-conceptualizing the domestic as political, which offers a relevant theoretical framework for the study of the diverse channels of women's involvement in international politics over the centuries.

Much of the work undertaken in the UK traces the process of formal admission of women in different national foreign services across the globe. In her studies, Helen McCarthy (University of Cambridge) delivers path-breaking analyses on women's status and role in the British diplomatic service, taking stock of the evolution of women's career paths from the positions of clerical and support staff to experts and career diplomats. Drawing on letters, memoirs, personal interviews, and government records, she constructs the history of twentieth-century British female diplomats at different diplomatic postings around the globe and advances our knowledge on the social dynamics and relationships, surrounding 
the integration of the first female officers in a world revolving around a masculine model of professionalism for many decades (McCarthy 2009, 2014). Together with James Southern, McCarthy provides a broader historical survey of women, gender, and diplomacy, conceptualizing the notion of female agency in international politics (McCarthy and Southern 2018). The notion of women's agency is developed also by Rhodri Jeffrey-Jones (University of Edinburgh) in his study on the histories of women who have shaped American foreign policy through their influence in international politics since World War I (Jeffrey-Jones 1995).

Decisive impulses for the development of feminist diplomatic histories have come from Austria, Germany, Ireland, Norway, Turkey, and Sweden. The major strand of the European literature refers to countryspecific research, with a focus on women's expanding role in the different foreign services across the globe, both as serving officers and as diplomatic spouses (Barrington 2017; Biltekin 2016; Rumelili and SuleymanogluKurum 2018; Erlandsson 2019; Hughes 2010; O’Brien 2019; Neumann 2012). Insightful analyses and detail-rich accounts on the history of women in German, Austrian, and Swiss diplomacy have been published in German (Bastian 2013; Bastian et al. 2014; Motschmann edt. 2018; Müller and Scheidemann 2000; Nolde 2013). Their translation into English would significantly contribute to constructing a more complete cross-national picture on the history of gender in European diplomacy.

These diverse historical recoveries offer a solid framework for exploring the struggle for gender equality in diplomacy across the globe. The high proliferation of case-studies on gender and diplomatic history now calls for more synthesizing approaches, which have the potential to explain broader international patterns of change and continuity in regard to women's empowerment and place in the global diplomatic sphere.

The second major thematic strand of European feminist scholarship in the field examines the changing gender character of diplomacy with a focus on the gender norms, practices, relations, and hierarchies at current diplomatic institutions. The most vital contributions within this realm come from Sweden. Ann Towns (University of Gothenburg) and Karin Aggestam (Lund University) are arguably the most influential exponents of this approach. Their collaborative work over the last few years has significantly advanced our understanding on the gendered nature of diplomacy. In 2017, Aggestam and Towns co-edited the first book on the topic of gender and diplomacy in the contemporary era. Gendering Diplomacy and International Negotiation brings together 
leading scholars in the field to discuss fundamental questions about the place, status, and visibility of women and contemporary diplomacy, about the gendered nature of diplomatic infrastructure and institutions, and about the masculinized norms and homosocial environments characterizing the field (Aggestam and Towns 2017a). Aggestam and Towns raise significant issues, previously missing from the agenda of diplomatic scholarship-e.g. how do changes in the homosocial features of diplomacy and the arrival of a more diverse set of actors impact the practice of diplomacy and international negotiation, and which are the gendered hierarchies that remain resistant to change (Aggestam and Towns 2017a: 13). Enriched with novel empirical analyses of case-studies from a broad geographical range (Sweden, Brazil, US, Turkey, Russia, as well as the UN and the $\mathrm{EU})$, the volume provides the first systematic attempt toward revealing broader international trends and patterns on the gendered practices and norms in diplomacy and international negotiation.

In their further collaborative work, Aggestam and Towns offer a pathbreaking research agenda for the advance of gender turn in diplomacy, opening up many new directions for scholarly inquiry and providing an inspiring framework for future work (Aggestam and Towns 2017b; Aggestam and Towns 2019). In collaboration with other scholars, they have built a solid knowledge base, which has illuminated much on women's representation and empowerment in foreign policy and diplomacy (Aggestam and True 2020; Aggestam and Svensson 2018; Towns et al. 2018; Towns and Niklasson 2017).

Another Scandinavian scholar and former Norwegian diplomat, Iver Neumann (Fridtjof Nansens Institute, Norway) offers particularly interesting viewpoints on the ways in which masculine values and worldviews have shaped diplomacy. Neumann explores different performances of masculinity and femininity within the Norwegian MFA and analyzes how diplomats' experiences of being female shape their roles, visibilities, and experiences in diplomacy. His major contribution lies in a historically informed ethnographic approach to gender in diplomacy and the application of the fundamental yet under-researched concepts of masculinity and femininity to the study of diplomatic practices, identities, and norms (Neumann 2008; 2012, 2019). Neumann's notion of feminine traits in diplomacy is further developed by Birgitta Niklasson (University of Gothenburg) in the first of its kind detailed study on the gendered networking of diplomats (Niklasson 2020). 
In Jennifer Cassidy's (University of Oxford) edited book "Gender and Diplomacy", a group of distinguished scholars and practitioners present detailed discussions of the role of women in diplomacy in a context which is historical, theoretical, and empirical. Framing the exploration of the historical and present experiences of women in the diplomatic sphere through the concepts of gender, institutional power, and leadership roles, the volume provides a solid empirical and theoretical contribution to the re-conceptualization of diplomacy as a gendered practice and study (Cassidy edt. 2017). The work of several scholars based in the Czech Republic further reflects the growing vitality of the second realm of feminist scholarship in Europe on diplomacy and international negotiation (Devine Mildorf 2019; Devine Mildorf et al. 2020).

Another vibrant body of scholarly work studies explicitly the role of women in international negotiation. Several recent contributions suggest a variety of viewpoints on women specifically as international mediators and map their place and status in mediation processes (Aggestam and Svensson 2018; Federer 2016; Paffenholz 2018; Naurin and Naurin 2018; Tryggestad 2018). Equally intriguing and complex, the search for an explanation of gender patterns in international negotiation is concentrated in European states that pursue the Women, Peace, and Security Agenda of the United Nations (most notably-the UK, Sweden, Switzerland, Finland, and the Netherlands) and invest efforts in advancing gender equality in foreign affairs, including through enhanced women's participation in negotiation processes.

\section{Feminist Scholarship in Europe on Diplomacy AND INTERNATIONAL NEgOTIATION-ThEORETICAL Approaches, Methodological Challenges, AND Avenues for Future Research}

Taken together, most of the feminist work on diplomacy produced in Europe takes departure in women's absence from, or underrepresentation in foreign affairs, and is informed by feminist international relations theory. Embedded within critical IR thought, it seeks to unveil how, traditionally and historically, women and feminine attributes have been excluded from (the study of) international politics. Feminist academic scholarship in Europe is now part of broader feminist IR debates arguing for the relevance of gender in challenging the theoretical 
and methodological underpinnings of the field. Theoretical perspectives on gender and diplomacy from within disciplines beyond IR, such as sociology, anthropology, or cultural studies, are still scarce, however.

Most of the feminist diplomatic history scholarship in Europe is inspired by methods and approaches at the intersection of history, gender studies, and feminist international relations. Informed by the concept of female agency, much scholarship is qualitative in nature and engages with descriptive case-studies of individual women and/or national MFAs. A major commonality of diplomatic history approaches is their broad conceptualization of the diplomatic arena as a field, influenced by a diverse set of actors, beyond formal political and diplomatic elites. Perhaps this is the reason why feminist knowledge production in the area of diplomatic history is so varied in form, including academic writing (books and peerreviewed publications), biographies, auto-biographies, policy papers, and popular writing (novels).

The vitality of feminist diplomatic histories notwithstanding, the need of more qualitative research on the history of women in diplomacy remains. There is still tantalizingly little known about twentieth-century female diplomats and their lives. In most countries around the globe, the process of opening the diplomatic service to women occurred within living memory. The promotion of women to the rank of ambassador is an even more recent trend, and many of the first female ambassadors were until recently acting diplomats. The time is thus ripe for the translation of their memories and lived experiences into conceptual knowledge that will advance the theorization of gender in diplomacy, relying on inside perspectives and offering concrete ways to link everyday life inquires to broader processes and patterns in international politics. The field also remains in demand of historical analyses that are more diverse in geographical scope, analyses which can provide solid foundation for future comparative studies and can theorize change and continuity in the gendered character of diplomacy beyond Western and Northern Europe.

Located mostly within critical IR, scholarship in Europe on the transformation of the gendered character of contemporary diplomacy grounds its credibility in theories and methodologies inspired by a range of critical feminist IR perspectives. Some of the studies approach female diplomats as tokens and analyze women's empowerment in diplomacy both through the prism of human agency and through institution-based approaches (e.g. Niklasson 2020). The majority of the accounts are qualitative 
in nature, with very few studies providing cross-national quantitative data concerning women's place in contemporary diplomacy (Towns and Niklasson 2017; Schiemichen 2019). More diverse quantitative data is needed to complement qualitative analyses and to contribute to identifying, comparing, and generalizing broader trans-national patterns in the transformation of gender relations in diplomacy and international negotiation both within and beyond Europe.

Maintaining sustained access to diplomatic professional circles and the environment in which they operate is central to such an agenda, yet it remains problematic. Despite the general trend toward public diplomacy, MFAs remain dominated by the rules of secrecy and low transparency and continue to resist the idea of being transformed into research objects by scholars, even in more advanced democracies (Lequesne 2020: 1). Diplomats themselves operate in environment of strict hierarchical rules and different controlling mechanisms (e.g. surveillance by national security agencies) and are traditionally cautious in providing information to external parties, especially when sensitive issues such as gender, race, sexuality, and human security are concerned.

This may partially explain why the field remains ripe for studies that approach gender and diplomacy through sociological, ethnographic, and anthropological perspectives. Logistical problems pose significant limitations for scholars to apply a more diverse set of research approaches and methods, e.g. participant observation or fieldwork among diplomats. Politics of restricted access remain one of the main structural challenges confronting European feminist scholars in the field today, and a significant hindrance to scholarly efforts to theorize gender in diplomacy through perspectives from within disciplines beyond IR.

Another issue of concern is the fact that certain women and men continue to be excluded from the study on gender and diplomacy. Feminist diplomacy scholarship in Europe has not examined the intersection of race, sexuality, and gender. LGBT issues and the contemporary representation of lesbian, gay, and bisexual persons in diplomacy and international negotiation have been object of surprisingly little scientific scrutiny (Crowe et al. 2018; Domeier 2013; Green 2015). While explicit attempts to incorporate a LGBT agenda into academic fare are still controversial and difficult to sustain in some European countries, silences in the field have been recently highlighted and criticized, and hopefully there will be developments toward queer studies in the field. 
It is important also to emphasize that questions about gender in diplomacy center predominantly on women, examining gender in diplomacy through the experiences and perspectives of women. What has less frequently been the focus of scholarly discussions is the gendered experiences of male diplomats within a gender order, and in their relation to women. ${ }^{3}$ Theorizing the changing gender character of diplomacy requires the consideration of men as well as women and better understanding of the social construction and representations of both femininity and masculinity within a common gender order.

\section{Conclusions}

Over the last decade, feminist knowledge production in Europe on diplomacy and international negotiation has been characterized by a growing vitality and diversity in research scopes, themes, methods, and approaches and has evidenced a significant potential to capture dynamics of continuity and change in the gendered character of diplomatic practices and institutions. Acknowledging the value of much existing critical work, this chapter suggested some areas of weakness such as the importance of looking beyond west-centric gender research and the need to rethink what feminist scholarship involves within the different socio-political contexts of Europe and the world.

The geographical and thematic mapping conducted in this chapter pointed to some key insights in terms of whether and how politics of location might influence the types of feminist knowledge that emerge across the different national contexts of Europe and suggested some important nuances as to which themes are being researched most intensively in which countries. Accordingly, we can identify certain national patterns of research interest in the field-while UK-based, German and Austrian scholars more often engage with historical studies on women's role in diplomacy, scholars based in the Scandinavian states exhibit stronger interest toward contemporary gender patterns, and the gendered norms, identities, and relations at current diplomatic institutions. Also, while diplomatic history scholarship is created by male and female researchers on a proportional basis, scholars engaged with gender in contemporary diplomacy are predominantly women.

${ }^{3}$ For important exception see Neumann (2008, 2012). 
A major point of commonality between the two major streams of feminist thought in Europe on diplomacy is the fact that their development has been incentivized by certain social and political circumstances, including the prioritization of women's issues in national foreign policy agendas. The UK, Sweden, Norway, Germany, etc., are states concerned with advancing pro-gender norms in foreign affairs, which provides an enabling context for researchers to produce feminist knowledge and to participate in international feminist debates in the field.

There could not be a better evidence for this trend than the sharp geographical discrepancy between feminist knowledge production on diplomacy in the different parts of Europe. The mapping suggests that feminism-both as a social phenomenon and as a general analytical perspective-is valued differently across the national contexts of Europe. In most of the Eastern, Central, and Southeastern European countries, feminist ideas continue to be met with hostility and distrust, and the very concept of gender remains confronted with negative connotations and is deprived of public and scholarly legitimacy. This alarming tendency is reflected not only in the lack of feminist scholarly production, but also in the practice of silencing international feminist debates in public and academic discourses across these regions.

Feminist scholarship on diplomacy and international negotiation beyond Western and Northern Europe is thus hardly an emerging field. It is still an open question whether and how the academic feminist expertise accumulated in Western Europe and the Scandinavian states could be effectively imported to, and consumed by, the "other" Europe. Perhaps the adoption of a gender mainstreaming agenda in the foreign policy of more European states would stimulate the relevant scientific debates and the creation of feminist knowledge in the field.

Turning to the future, the importance of feminist approaches to the study of diplomacy and international negotiation will continue to grow in importance, not least since both the diplomatic world and diplomatic studies remain male-dominated. Against the background of growing concerns about the future of liberal democracies and an unprecedented bio-political crisis, women's voices in higher level decision-making and international negotiation will play a vital role in overcoming power inequalities in public and private life, and in creating a more sustainable future. 


\section{REFERENCES}

Aggestam, K. and Svensson, I. (2018). Where are the women in peace mediation? In: K. Aggestam and A. Towns, eds. Gendering diplomacy and international negotiation. Basingstoke: Palgrave Macmillan. pp. 149-168.

Aggestam, K. and Towns, A. (2019). The gender turn in diplomacy: A new research agenda. International Feminist Journal of Politics 21 (1): 9-28.

Aggestam, K. and Towns, A. (eds). (2017a). Gender in diplomacy and international negotiation. London: Palgrave Macmillan.

Aggestam, K. and Towns, A. (2017b). Diplomacy-A gendered institution. In: P. Kerr and G. Wiseman, eds. Diplomacy in a globalizing world. Oxford: Oxford University Press.

Aggetsam, K. and True, J. (2020). Gendering foreign policy: A comparative framework for analysis. Foreign Policy Analysis 16 (2): 143-162.

Barrington, A. (2017). From marriage bar towards gender equality: The experience of women in Ireland's Department of Foreign Affairs, 1970-2000. In: J. Cassidy, ed. Gender and diplomacy. London and New York: Routledge. pp. $48-65$.

Bastian, C. (2013). Verbandeln in Briefen: Frauen in der höfischen Diplomatie des frühen 18. Jahrbunderts. 1. Auflage. Köln: Böhlau Köln.

Bastian, C., Dade E., von Thiessen H. and Windler, C. (eds.). (2014). Das Geschlecht der Diplomatie. Geschlechterrollen in den Außenbeziehungen vom Spätmittelalterbiszum 20. Jahrhundert. Externa: Vol. 5, Köln, Böhlau.

Biltekin, N. (2016). Servants of diplomacy: The making of Swedish diplomats, 1905-1995. Stockholm: Department of History.

Bucur, M. (2008). An archipelago of stories: Gender history in Eastern Europe. The American Historical Review 113 (5): 1375-1389.

Cassidy, J. (edt.). (2017). Gender and diplomacy. London and New York: Routledge.

Crowe, K., Hamilton, K. and Southern, J. (2018). Women and the Foreign Office: A history. Foreign and Commonwealth Office. History Notes: Issue 20. [online].

Daybell, J. (2004). Women and politics in early modern England. Aldershot: Ashgate.

Daybell, J. (2011). Women, news and intelligence networks in Elizabethan England. In: R.J. Adams and R. Cox, eds. Diplomacy and early modern culture. Basingstoke: Palgrave. pp. 101-120.

Daybell, J. and Norrhem, S. (2016). Gender and political culture in early modern Europe, 1400-1800. London: Routledge.

Devine Mildorf, J. (2019). The issues facing partners and spouses of European diplomats: A gender perspective. Institute of International Relations Prague. [online]. 
Devine Mildorf, K. and Dopita, T. (2020). Inside diplomacy: how to deal with gender inequality in Foreign service [Uvnitř diplomacie: Jak na genderovou nerovnost v zahraniční službě]. Prague: Grada.

Domeier, N. (2013). Das dritte Geschlecht der Diplomatie. Die Außenpolitik des wilhelminischen Deutschland unter dem Verdacht der Homosexualität. In. C. Bastian (Hg.), Das Geschlecht der Diplomatie. Geschlechterrollen in den Außenbeziehungen vom Spätmittelalter bis zur Gegenwart. Köln/Weimar/Wien. pp. 181-200.

Federer, J. (2016). On gender: The role of norms in international peace mediation. [online].

Erlandsson, S. (2019). Off the record: Margaret van Kleffens and the gendered history of Dutch World War II diplomacy. International Feminist Journal of Politics 21 (1): 29-46.

Green, B. (2015). LGBT Diplomacy in the UK. Public Diplomacy Magazine 13: 25-29.

Hughes, V. (2010).Women, gender, and Canadian foreign policy, 1909-2009. British Journal of Canadian Studies 23 (2): 159-178.

Jeffreys-Jones, R. (1995). Changing differences: Women and the shaping of American foreignpolicy, 1917-1994. New Brunswick: Rutgers University Press.

Krizsan, A. and Roggeband, C. (eds.). (2019). Gendering democratic backsliding in Central and Eastern Europe: A comparative agenda. Budapest: Central European University.

Lequesne, Ch. (2020). Ministries of Foreign Affairs: A critical institution revisited. The Hague Journal of Diplomacy 15 (1-2): 1-12.

Lindstrom, P. and Norrhem, S. (2017). Diplomats and kin networks: diplomatic strategy and gender in Sweden, 1648-1740. In: J. Daybell and S. Norrhem, eds. Gender and political culture in early modern Europe. Routledge. pp. 6887.

McCarthy, H. (2009). Petticoat diplomacy: The admission of women to the British foreign service, 1919-1946. Twentieth Century British History 20 (3): 285-321.

McCarthy, H. (2014). Women of the world: The rise of the female diplomat. London: Bloomsbury.

McCarthy, H. and Southern, J. (2018). Women, gender and diplomacy: A historical survey. In: J. Cassidy, ed. Gender and Diplomacy. London and New York: Routledge. pp. 15-31.

Motschmann, E. (ed.). (2018). Female diplomacy. Frauen in der Außenpolitik. Freiburg: Herder Verlag.

Müller, U. and Scheidemann, Ch. (2000). Gewandt, Geschickt und Abgesandt. Frauen im Diplomatischen Dienst. München: Olzog Verlag. 
Naurin, D. and Naurin, E. (2018). Descriptive representation and negotiation. In: K. Aggestam and A. Towns, eds. Gendering diplomacy and international negotiations. Basingstoke: Palgrave Macmillan. pp. 213-238.

Neumann, I. (2008). The body of the diplomat. European Journal of International Relations. 14 (4): 671-695.

Neumann, I. (2012). At Home with the diplomats: Inside a European foreign ministry. Ithaca, NY: Cornell University Press.

Neumann, I. (2019). Concepts of international relations, for students and other smarties. University of Michigan Press.

Nolde, D. (2013). Was ist Diplomatie und wenn ja wie viele? Herausforderungen und Perspektiven einer Geschlechtergeschichte der frühneuzeitlichen Diplomatie. In: P. Burschel and B. Kundrus, (Hg.) Historische Anthropologie 21 (2): 179-198.

Niklasson, B. (2020). The gendered networking of diplomats. The Hague Journal of Diplomacy 15 (1): 13-42.

O'Brien, A. (2019). A century of change: The (in)visibility of women in the Irish Foreign Service, 1919-2019. Irish Studies in International Affairs 30: 73-92.

Paffenholz, T. (2018). Women in peace negotiations. In: K. Aggestam and A. Towns, eds. Gendering diplomacy and international negotiations. Basingstoke: Palgrave Macmillan. pp. 169-192.

Rumelili, B. and Suleymanoglu-Kurum, R. (2018). Women and gender in Turkish diplomacy: Historical legacies and current patterns. In: K. Aggestam and A. Towns, eds. Gendering Diplomacy and International Negotiations. pp. 87-106.

Schiemichen, L. (2019). Madam Ambassador: A statistical comparison of female ambassadors across the U.S., German, and EU foreign services. College of Europe Studies. EU Diplomacy Papers 3/2019. [online].

Towns, A. and Niklasson, B. (2017). Gender, international status, and ambassador appointments. Foreign Policy Analysis (13): 521-540.

Towns, A., Kreft, A. and Niklasson, B. (2017).The empowerment of women in diplomacy. In: A. Alexander, C. Bolzendahl and F. Jalazai, eds. Measuring women's political empowerment across the globe: Strategies, challenges and future research. New York: Palgrave Macmillan. pp. 187-205.

Tryggestad, T. (2018). Negotiations at the UN. In: K. Aggestam and A. Towns, eds. Gendering Diplomacy and International Negotiations. Basingstoke: Palgrave Macmillan. pp. 239-258. 
Open Access This chapter is licensed under the terms of the Creative Commons Attribution 4.0 International License (http://creativecommons.org/licenses/ by $/ 4.0 /$ ), which permits use, sharing, adaptation, distribution and reproduction in any medium or format, as long as you give appropriate credit to the original author(s) and the source, provide a link to the Creative Commons license and indicate if changes were made.

The images or other third party material in this chapter are included in the chapter's Creative Commons license, unless indicated otherwise in a credit line to the material. If material is not included in the chapter's Creative Commons license and your intended use is not permitted by statutory regulation or exceeds the permitted use, you will need to obtain permission directly from the copyright holder.

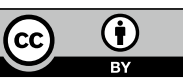

